\title{
PENGARUH KONSENTRASI PENSTABIL DAN SUKROSA TERHADAP KARAKTERISTIK SARI BONGGOL NANAS (Ananas comosus $l$. merr) INSTAN DENGAN METODE KOKRISTALISASI
}

\author{
Ina Siti Nurminabari, Wisnu Cahyadi, Ramadiansyah \\ Program Studi Teknologi Pangan, Fakultas Teknik, Universitas Pasundan, Jl. Dr.Setiabudi No 93, Bandung, 40153, \\ Indonesia \\ E-mail : $\underline{\text { inasitinurminabari@unpas.ac.id }}$
}

\begin{abstract}
Pineapple is one of the fruit plants that has long been widely known by the public. Pineapple is not native to Indonesia, this plant comes from the American continent. The purpose of this study was to study the effect of CMC stabilizer and sucrose concentration on the characteristics of instant pineapple cork extract (Ananas comosus L. merr) with the cocrystallization method. The benefit of this research is to add insight to the research, add and develop science and technology regarding pineapple hump juice as food preparations, and to lift local raw materials that have not been utilized so that they have added value and increase the use value and economic value of pineapple corm. The experimental design method used in the study of cocrystallization of pineapple hump juice was a $3 \times 3$ factorial experimental design in a randomized block design (RBD), carried out 3 (three) times repetition, to obtain 27 experimental units. The experiment variable consisted of CMC (p) and sucrose (s) stabilizer concentration. The response in this study is the chemical response, namely reducing sugar content, crude fiber content, vitamin $\mathrm{C}$ content, water content. Physical response is soluble time. Organoleptic responses include aroma, color, and taste. The results showed that the levels of vitamin C extract of pineapple extract in the introduction were $55.73 \mathrm{mg} / 100$ grams, the reduction level of pineapple cusp extract was $18.92 \%$, and the crude fiber content of pineapple cusp extract was $0.953 \%$. The results of the main research testing that the concentration of CMC stabilizer and sucrose affect the water content, soluble time, organoleptic response, namely color, and aroma. The interaction between stabilizer and sucrose concentrations influences the water content, when soluble the organoleptic response to color, and Rome.
\end{abstract}

Keywords: crystallization, pineapple hump, CMC stabilizer, and sucrose

\section{Pendahuluan}

Nanas merupakan salah satu tanaman buah yang sudah lama dikenal luas oleh masyarakat. Nanas atau pineapple bukan merupakan tanaman asli Indonesia. Tanaman ini berasal dari benua Amerika (Rukmana, 1996). Produksi nanas Indonesia cukup besar. Berdasarkan Angka Tetap (ATAP) tahun 2015 produksi nanas mencapai 1,73 juta ton. Berdasarkan data rata-rata produksi tahun 2011-2015, sebanyak 73,08\% produksi nanas Indonesia dipasok dari Provinsi Lampung, Jawa Barat, Sumatera Utara, Jawa Timur, dan Jambi. Lampung memberikan kontribusi terbesar terhadap produksi nanas Indonesia, yaitu sebesar $32,77 \%$, diikuti oleh Jawa Barat (10,39\%), Sumatera Utara (12,78\%), Jawa Timur $(8,92 \%)$, dan Jambi $(8,23 \%)$, sedangkan provinsi-provinsi lainnya memberikan kontribusi terhadap produksi nanas Indonesia kurang dari 7\% (Kementrian Pertanian 2016).

Sedangkan di Kabupaten Subang, nanas berkembang di beberapa kecamatan dengan ketinggian tempat dari 300-500 meter dari permukaan laut antara lain di kecamatan Jalancagak, Cisalak, Cijambe, Kasomalang, Subang, Tambakmekar. Serang Panjang, Ciater. Jumlah produksi buah nanas di Kabupaten Subang 64,321,494 ton (Sumber: Dinas Pertanian Tanaman Pangan Kabupaten Subang, 2013).
Buah nanas selain dikonsumsi dalam bentuk segar juga diolah menjadi berbagai produk seperti sirup, sari buah, selai, jeli, asinan, manisan, keripik atau buah yang dibotolkan atau diawetkan dengan cara pengalengan. Proses pengolahan nanas ini limbah hati nanas serta bagian lain yang tidak dimakan. Limbah buah bonggol nanas merupakan limbah padat yang dihasilkan dari pabrik atau pengrajin pengolahan buah nanas. Dari pabrik pengolahan buah nanas hasil pengrajin di daerah Desa Tambaksari Kecamatan Jalancagak Kabupaten Subang. Dari $100 \mathrm{~kg}$ buah nanas segar varietas Cayenne didapatkan limbah bonggol nanas sebanyak $35 \%$, limbah kulit dan sisa irisan daging buah diperoleh sebanyak $12 \%$, sedangkan sisanya sebagai daging buah sebanyak $53 \%$. Sedangkan sisanya dibuang sebagai limbah. Sehingga limbah nanas semakin lama semakin menumpuk dan umumnya hanya dibuang sebagai sampah atau pakan ternak. Hal tersebut membuka peluang dalam pemanfaatan limbah nanas berupa bonggol nanas. Sebagaimana diketahui bahwa bahan-bahan sisa ini didalamnya masih terkandung sari buah yang mengandung gula dan asam. Menurut Pracaya (1985) dalam Sucipto (2006), terkandung gula sebanyak 75 sampai $85 \%$, asam sitrat 7 sampai $9 \%$, protein 2,4 sampai $4 \%$ serta mineral-mineral seperti kalium, kalsium dan magnesium yang merupakan media yang baik untuk pertumbuhan mikrooganisme. 
Bonggol nanas tanpa perlakuan tidak akan tahan lama, karena mengalami kerusakan dengan cepat yang di tandai dengan timbulnya bau yang kurang enak (bau asam). Untuk menyimpan dan memperpanjang daya simpan, juga memberi nilai ekonomi pada bonggol nanas maka perlu dikembangkan cara-cara pengolahan sekaligus pengawetan bonggol nanas. Untuk menangani limbah hati nanas agak tidak terbuang begitu saja, cara yang akan dilakukan dalam penelitian ini salah satunya adalah dengan mengolah bonggol nanas menjadi olahan minuman instan dengan metode kokristalisasi sari bonggol buah nanas. Pemilihan bonggol buah nanas (Ananas comasus 1. merr) varietas cayenne sebagai bahan baku pembuatan kokristalisasi sari bonggol buah nanas, karena semakin berkembangnya industri pengolahan buah nanas maka akan meningkatkan harga nilai jual itu sendiri. Dimana bonggol nanas merupakan hasil samping dari pengolahan industri tersebut, harganya relatif murah, dan buah ini tidak mengenal musim sehingga dapat diperoleh dengan mudah (Firmansyah, 2008). Pengolahan buah-buahan menjadi kokristalisasi sangat bermanfaat untuk pengawetan dan penganekaragaman produk pangan, seperti halnya dengan pengolahan limbah bonggol nanas menjadi olahan kokristalisasi sari bonggol buah nanas yang merupakan salah satu alternatif pengolahan dari limbah industri pengolahan buah nanas.

Kokristalisasi sari bonggol nanas adalah merupakan usaha pengembangan produk minuman instan olahan buah, yaitu mengolah bonggol nanas yang diambil sari bonggolnya menjadi kristalisasi yang dicampur sukrosa (gula pasir). Proses kokristalisasi sari bonggol nanas meliputi penambahan sukrosa. Menurut (Burhanudin 2003), penambahan sukrosa ini akan dapat berpengaruh terhadap karakteristik kokristalisasi salah satunya adalah tekstur, rasa, dan warna yang diinginkan, serta untuk memperoleh kristalisasi dengan penampakan yang baik.

Prinsip dari kokristalisasi adalah berdasarkan proses kristalisasi gula dengan cara proses larutan gula lewat jenuh dan bubur buah pada proses pemanasan. Berdasarkan SNI 01-4320-1996, minuman tradisional berbentuk serbuk harus memiliki kadar air maksimal 3 $\%$ b/b, kadar abu maksimal 1,5\% b/b, dan jumlah gula maksimal $85 \%$ b/b.

Penambahan sukrosa dalam pembuatan kokristaisasi yaitu untuk membuat larutan lewat jenuh sehingga mengkristalkan sari bonggol nanas untuk dijadikan produk minuman instan, keuntungan penggunaan sukrosa harga relarif murah, dapat larut dengan cepat, memiliki masa simpan yang cukup lama, relatif stabil terhadap pengaruh suhu panas, serta memberikan aroma yang baik. Menurut (Bennion dkk., 1980, dalam Iffah 2006). Kadar sukrosa yang terlalu rendah tidak dapat menyilimuti bubur buah yang berfungsi sebagai inti sel pada granula mikrokapsul. Sebaliknya, kadar sukrosa yang terlalu tinggi akan memberikan rasa yang kurang seimbang antara bubur buah dan rasa manis dari sukrosa, sehingga flavor asli dari buah tidak akan terasa. Menurut (Ngakan, 1994, dalam Siddiq 2005), apabila suhu terlalu panas dan air yang terkandung dalam gula tersebut habis maka akan terjadi browning atau warna coklat yang tidak dikehendaki dan tidak higroskopi, serta memiliki masa simpan yng cukup lama.

Metode kokristalisasi merupakan salah satu teknik dalam proses mikroenkapsulasi. Mikroenkapsulasi dapat didefinisikan sebagai langkah atau aktivitas yang secara umum mirip dengan teknologi pengemsan yang dalam hal ini pengemasan suatu zat padat, cair atau gas ke dalam suatu bentuk mikrokapsul yang sewaktu-waktu dapat melepaskan zat tersebut dalam kondisi tertentu. (Ngakan, 1997).

Kokristalisasi hanya dapat terjadi jika larutan sukrosa keadaan lewat jenuh. Pada larutan sukrosa super jenuh yang diproses melalui pengkonsentrasian, ditambahkan material aroma dengan proses pengadukan yang akhirnya menyebabkan campuran sukrosa dan bubur buah mengalami kristalisasi (Ngakan, 1994 dalam Siddiq, 2005)

Bonggol nanas sendiri mempunyai daya serat yang tinggi sehingga dapat menyebabkan penggumpalan atau pengendapan pada suatu produk sehingga perlu penambahan bahan penstabil. Bahan penstabil adalah zat yang dapat menstabilkan, mengentalkan atau memekatkan makanan yang dicampur dengan air untuk membentuk kekentalan tertentu. Penstabil yang digunakan adalah carboxy methyl celllose (CMC). CMC berfungsi untuk mempertahankan kestabilan minuman agar partikel padatannya tetap terdispersi keseluruh bagian sehingga tidak mengalami pengendapan. CMC dapat memperbaiki citarasa, warna dan konsistensi (Kamal 2010). Menurut Tranggono (1988) dalam Siddiq (2005). Untuk mencegah pembentukan gumpalan atau endapan partikel-partikel koloid yang dapat mengurangi nilai penampakan diperlukan penambahan penstabil seperti CMC.

Berdasarkan uraian di atas maka perlu dilakukan penelitian untuk mengetahui pengaruh konsentrasi penstabil dan sukrosa terhadap karakteristik kokristalisasi sari bonggol nanas.

\section{Metode Penelitian}

Bahan utama yang digunakan dalam penelitian ini adalah bonggol nanas varietas Cayenne yang diperoleh dari kebun nanas di daerah Jalancagak Subang Jawa Barat dengan berat buah nanas 500 gram dan tingkatan kematangan berumur 6 bulan, bahan untuk penunjang lainnya digunakan sukrosa yang diperoleh dari pasar sederhana dengan berat 500 gram, CMC dengan merk koepe-koepe diperoleh dari hypermart.

Bahan analisis yang digunakan dalam penentuan kadar vitamin $\mathrm{C}$ (iodimetri) adalah As2O3, $\mathrm{NaOH} \mathrm{0,1}$ $\mathrm{N}, \mathrm{NaHCO} 3, \mathrm{I} 2$. Analisis kadar serat kasar (gravimetri) adalah CHCL3, $\mathrm{NaOH} 0,3 \mathrm{~N}, \mathrm{H} 2 \mathrm{SO} 4$. Kadar gula 
reduksi (luff shoorl) $\mathrm{H} 2 \mathrm{SO} 46 \mathrm{~N}, 1$ gram KI, Na2S2O3 $1 \mathrm{~N}, \mathrm{NaOH} 30 \%$, aquadest dan $5 \mathrm{ml} \mathrm{HCl}$ pekat. Kadar air (gavimetri) dan waktu larut.

Alat-alat yang digunakan dalam penelitian ini adalah timbangan, batang pengaduk, sarung tangan karet, teplon, pengayakan, blender, talenan, pisau stainless steel, blender, spatula, timbangan, botol timbang, toples plastik.

Alat-alat yang digunakan dalam analisis kimia adalah gelas ukur, timbangan analitik, soxhlet, Erlenmeyer $600 \mathrm{ml}$, kertas saring, oven $110^{\circ} \mathrm{C}$, desikator, kaca arloji, biuret, pipet, refraktometer.

Pelaksanaan penelitian dalam pembuatan kokristalisasi bonggol nanas Subang atau varietas Cayenne ini meliput penelitian pendahuluan dan utama.

Penelitian pendahuluan dilakukan untuk menganalisis bahan baku kadar vitamin C (Metode Iodimetri, AOAC 1995), kadar gula reduksi (Metode Luff Schoorl AOAC 1995), dan kadar serat dengan menggunakan (Metode Gravimetri, AOAC 2005).

Penelitian utama merupakan lanjutan dari penelitian pendehaluan. Pada penelitian utama ini dilakukan penentuan konsentrasi penstabil yang paling tepat dengan variasi konsenrasi penstabil yaitu 0,2 \%, $0,4 \%$ dan $0,6 \%$. Sedangkan variasi penambahan konsentrasi sukrosa yang paling tepat yaitu $50 \%, 55 \%$ dan $60 \%$. Serta menganalisis kadar air menggunakan (Metode Gravimetri AOAC 1995), waktu larut dan kadar vitamin C (Metode Iodimetri, AOAC 1995).

Rancangan perlakuan yang dilakukan pada penelitian ini terdiri dari dua faktor. Faktor pertama adalah konsentrasi penstabil (P) yang terdiri dari 3 taraf dan faktor kedua adalah konsentrasi sukrosa (S) yang terdiri dari 3 taraf sehingga akan diperoleh 9 kombinasi perlakuan. Faktor perlakuan konsentrasi penstabil CMC (P) yang terdiri dari 3 taraf, yaitu : p1 $=0,2 \%$; p2 = $0,4 \%$; dan p3 $=0,6 \%$. Faktor perlakuan konsentrasi sukrosa (S) terdiri dari 3 taraf, yaitu: $\mathrm{s} 1=50 \%$; s2 $=$ $55 \%$; dan $\mathrm{s} 3=60 \%$. Rancangan percobaan yang digunakan pada penelitian ini adalah Rancangan Acak Kelompok (RAK) dengan pola faktorial $3 \times 3$ dengan ulangan sebanyak tiga kali, sehingga diperoleh 27 satuan percobaan.

Respon yang akan digunakan pada penelitian ini adalah respon kimia dan respon organoleptik. Respon kimia yang dilakukan terhadap prodak meliputi: kadar gula reduksi dengan menggunakan (Metode luff schoorl), kadar vitamin C (Metode Iodimetri, AOAC 1995), kadar air (Metode Gravimetri AOAC 1995), dan kadar serat dengan menggunakan (Metode Gravimetri, AOAC 2005). Respon fisik yang dilakukan terhadap produk meliputi waktu larut minuman kokristalisasi sari bonggol nanas. Respon organoleptik yang akan digunakan pada penelitian utama adalah pengujian hedonik (uji kesukaan), ini bertujuan untuk mengetahui sifat indrawi dari sampel terhadap warna, aroma, dan rasa. Sampel tersebut disajikan kepada 30 panelis dengan kode tertentu pada setiap sampel.

\section{Hasil dan Pembahasan \\ Hasil Penelitian Pendahuluan}

Penelitian pendahuluan dilakukan untuk mengetahui kadar Vitamin $\mathrm{C}$, kadar serat kasar, kadar gula reduksi sehingga dapat dilihat perbedaan hasil Vitamin $\mathrm{C}$ pada bahan baku sari buah nanas dengan produk terpilih di penelitian utama.

Tabel 1. Perbandingan Hasil Analisis Kadar Vitamin C dan Kadar Serat Kasar dari Sari Bonggol Nanas dan Buah Nanas.

\begin{tabular}{cccc}
\hline Nanas & $\begin{array}{c}\text { Vitamin C } \\
(\mathrm{mg} / 100 \\
\text { gram) }\end{array}$ & $\begin{array}{c}\text { Gula } \\
\text { Reduksi } \\
(\%)\end{array}$ & $\begin{array}{c}\text { Kadar } \\
\text { Serat } \\
\text { Kasar } \\
(\%)\end{array}$ \\
\hline $\begin{array}{c}\text { Bonggol } \\
\text { Nanas }\end{array}$ & 55,73 & 18.92 & 0,953 \\
\hline $\begin{array}{c}\text { Buah } \\
\text { Nanas * }\end{array}$ & 68,322 & - & 1,012 \\
\hline Keterangan: *Hutagulung, T., dkk.2015 &
\end{tabular}

\section{Hasil Penelitian Utama}

1. Kadar Vitamin C

Berdasarkan hasil analisis variansi (ANAVA) menunjukkan bahwa konsentrasi penstabil CMC (P) dan konsentrasi sukrosa $(\mathrm{S})$ berpengaruh terhadap kadar vitamin $\mathrm{C}$ kokristalisasi sari bonggol nanas, sedangkan konsentrasi CMC serta interaksi antara konsentrasi sukrosa tidak berpengaruh. Pengaruh konsentrasi penstabil CMC (P) terhadap kadar vitamin C kokristalisasi sari bonggol nanas dapat dilihat pada Tabel 2 dan 3 .

Tabel 2. Uji Lanjut Duncan Konsentrasi CMC Kadar Vitamin C (mg/100gram) Kokristalisasi Sari Bonggol Nanas

\begin{tabular}{ccc}
\hline Perlakuan & Nilai rata-rata & $\begin{array}{c}\text { Taraf nyata } \\
\mathbf{5 \%}\end{array}$ \\
\hline Penstabil & 37,19 & $\mathrm{a}$ \\
$\mathrm{CMC}\left(\mathrm{p}_{3}\right)$ & & \\
$0,6 \%$ & & $\mathrm{~b}$ \\
\hline Penstabil & 40,92 & \\
$\mathrm{CMC}\left(\mathrm{p}_{2}\right)$ & & $\mathrm{c}$ \\
$0,4 \%$ & & \\
\hline Penstabil & 42,63 & \\
CMC $\left(\mathrm{p}_{1}\right)$ & & \\
$0,2 \%$ & & \\
\hline Keterangan : Nilai rata-rata yang ditandai dengan huruf yang sama
\end{tabular}
menunjukkan tidak berbeda nyata pada taraf 5\% menurut uji lanjut Duncan

Semakin tinggi konsentrasi penstabil CMC dan maka kadar vitamin $\mathrm{C}$ akan semakin meningkat. Menurut Puteri (2015) meningkatnya CMC maka bahan-bahan akan stabil dan vitamin $\mathrm{C}$ yang mudah larut dalam air dapat diikat oleh CMC sehingga kerusakan vitamin $\mathrm{C}$ akan semakin kecil. Pada analisis kadar vitamin C kokristalisasi sari bonggol nanas dengan penambahan penstabil CMC terjadi penurunan. Hal tersebut 
disebabkan oleh sifat vitamin $\mathrm{C}$ yang mudah rusak. Disamping itu pada pembuatan kokristalisasi sari bonggol nanas dilakukan proses pemasakan sehingga akan terjadi penurunann kadar vitamin $\mathrm{C}$.

Tabel 3. Uji Lanjut Duncan Konsentrasi Sukrosa Kadar Vitamin C (mg/100gram) Kokristalisasi Sari Bonggol Nanas

\begin{tabular}{|c|c|c|}
\hline Perlakuan & Nilai rata-rata & $\begin{array}{c}\text { Taraf nyata } \\
5 \%\end{array}$ \\
\hline Sukrosa $\left(s_{3}\right) 60 \%$ & 39.00 & $\mathrm{a}$ \\
\hline Sukrosa $\left(s_{2}\right) 55 \%$ & 40.12 & $\mathrm{~b}$ \\
\hline Sukrosa $\left(\mathrm{s}_{1}\right) 50 \%$ & 41,61 & $\mathrm{c}$ \\
\hline
\end{tabular}

Keterangan : Nilai rata-rata yang ditandai dengan huruf yang sama menunjukkan tidak berbeda nyata pada taraf $5 \%$ menurut uji lanjut Duncan

Pengaruh konsentrasi sukrosa terhadap vitamin C semakin tinggi konsentrasi sukrosa maka akan semakin menurun. Hal ini disebabkan terlalu lamanya proses pemanasan yang dimana semakin banyak konsentrasi sukrosa yang diberikan maka semakin lama, sehingga mengakibatkan kandungan yang terkandung pada sari bonggol nanas cepat rusak dan banyak yang hilang. Disamping sangat larut dalam air, vitamin $\mathrm{C}$ mudah teroksidasi dan proses tersebut dipercepat oleh panas, sinar atau enzim oksidasi, serta oleh katalis tembaga dan besi, oksidasi akan terhambat bila vitamin $\mathrm{C}$ dibiarkan dalam keadaan asam atau suhu rendah (Winarno, 1997).

\section{Kadar Air}

Kadar air merupakan komponen yang penting dalam bahan makanan karena air dapat mempengaruhi tekstur, penampakan dan cita rasa makanan pada umumnya. Penetapan kadar air dalam bahan makanan ini penting artinya untuk mengetahui kadar air dalam bahan makanan ini penting artinya untuk mengetahui kadar air sekaligus kadar air zat kering dalam makanan tersebut (Winarno, 1997).

Berdasarkan hasil analisis variansi pada lampiran 12 menunjukkan bahwa konsentrasi penstabil CMC (P), konsentrasi sukrosa (S) dan interaksinya (PS) berpengaruh tehadap kadar air kokristalisasi sari bonggol nanas. Hal ini dikarenakan produk ini berupa serbuk dimana serbuk memiliki luas permukaan yang lebih luas karena bentuk partikel-partikelnya lebih halus, hal ini menyebabkan air lebih mudah untuk menyerap. Pengaruh interaksi konsentrasi CMC dan sukrosa terhadap kokristalisasi sari bonggol nanas dapat dilihat pada Tabel 4.

Tabel 4 Uji Dwi Arah untuk Interaksi Penstabil CMC dan Sukrosa terhadap Kadar Air (\%) Kokristalisasi Sari Bonggol Nanas

\begin{tabular}{|c|c|c|c|c|}
\hline \multirow[b]{2}{*}{ CMC(P) } & \multicolumn{4}{|c|}{ Sukrosa (S) } \\
\hline & Sukrosa (s1) $50 \%$ & Sukrosa (s2) $55 \%$ & & $\frac{\text { Sukrosa (s3) }}{60 \%}$ \\
\hline $\begin{array}{c}\text { Penstabil CMC (p1) } \\
0,2 \%\end{array}$ & 2.975 & $b^{2.325}$ & & 1.974 \\
\hline $\begin{array}{c}\text { Penstabil CMC (p2) } \\
0,4 \%\end{array}$ & $c^{2.657}$ & $b^{2.302}$ & & 1.658 \\
\hline $\begin{array}{c}\text { Penstabil CMC (p3) } \\
0,6 \%\end{array}$ & $b^{2.141}$ & $a^{1.827}$ & & 1.649 \\
\hline
\end{tabular}

Keterangan : Setiap huruf yang berbeda menunjukkan perbedaan yang nyata pada taraf 5\%. Huruf besar dibaca vertikal dan huruf kecil dibaca horizontal.

Semakin tinggi konsentrasi penstabil CMC yang digunakan maka kadar air semakin turun. Hal tersebut disebabkan penambahan bahan penstabil akan meningkatkan padatan dalam produk sehingga kadar air semakin menurun, CMC dalam produk pangan berfungsi sebagai pengikat air dan pembentuk gel yang menghasilkan tekstur produk pangan. CMC berfungsi membentuk sistem disperse koloid dan meningkatkan viskositas sehingga partikel-partikel yang tersuspensi akan tertangkap dalam sistem tersebut dan tidak mengendap oleh pengaruh gaya gravitasi (Kamal, 2010).

Pengaruh penambahan sukrosa pada kokristalisasi sari bonggol nanas maka semakin rendah kadar air. Hal itu disebabkan karena salah satu sifat dari sukrosa adalah higroskopis, yaitu mempunyai kemampuan untuk mengikat air. Semakin banyak sukrosa yang ditambahkan maka semakin banyak pula air yang diikat dan menyebabkan kadar air menjadi rendah. Menurut (Buckle et al., 1987; Master, 1997; Winarno, 1997). jika konsentrasi sukrosa semakin tinggi maka akan menaikkan total padatan dari suatu bahan pangan, sehingga fraksi air dalam bahan pangan tersebut menjadi lebih kecil. Tinggi jumlah total padatan pada bahan yang akan dikeringkan, maka kadar air produk akan makin rendah, hal ini disebabkan karena padatan yang terdapat didalam bahan tersebut akan mempercepat laju pengeringan bahan dan lebih banyak air yang diuapkan. Ada tidaknya sifat pereduksi dari suatu molekul gula ditentukan oleh ada atau tidaknya gugus karboksil $(\mathrm{OH})$ bebas yang reaktif. Diduga pada gugus hidroksil itulah terjadi pengikatan hidrogen dengan molekul air disekitarnya. Selain itu proses pemanasan dan pengayakan saat kokristalisasi sari bonggol nanas yang dilakukan diruangan terbuka dapat menyebabkan terjadinya penyerapan air dari lingkungan sehingga kadar air semakin tinggi.

Kadar air dalam makanan perlu ditetapkan karena semakin tinggi kadar air yang terdapat dalam suatu makanan makin besar pula kemungkinan makanan tersebut cepat rusak atau tidak tahan lama (Winarno, 1997). 
Berdasarkan hasil analisis kadar air kokristalisasi sari bonggol nanas, dimana produk tersebut memiliki kadar air berkisar 1-3\% artinya sesuai dengan SNI 014320-1996 yaitu maksimal 3-5\%. Sehingga layak untuk dikonsumsi sebagai minuman serbuk. Batas kadar air minimum dimana mikroorganisme masih dapat tumbuh menurut Fardiaz (1992) adalah 14-15\%.

\section{Waktu Larut}

Berdasarkan hasil analisis variansi pada lampiran 13 menunjukkan bahwa konsentrasi penstabil CMC (P), konsentrasi sukrosa (S) dan interaksi (PS) berpengaruh terhadap waktu larut kokristalisasi sari bonggol nanas. Pengaruh interaksi konsentrasi penstabil CMC dan sukrosa terhadap waktu larut kokristalisasi sari bonggol nanas dapat dilihat pada Tabel 5.

Tabel 5. Uji Dwi Arah untuk Interaksi Penstabil CMC dan Sukrosa terhadap Waktu Larut (detik) Kokristalisasi Sari Bonggol Nanas

\begin{tabular}{|c|c|c|c|c|}
\hline \multirow{2}{*}{$C M C(P)$} & \multicolumn{4}{|c|}{ Sukrosa (S) } \\
\hline & Sukrosa (s1) $50 \%$ & Sukrosa (s2) 55 \% & & Sukrosa (s3) 60\% \\
\hline $\begin{array}{c}\text { Penstabil CMC (p1) } \\
0,2 \%\end{array}$ & 18.63 & 20.43 & & 23.36 \\
\hline $\begin{array}{c}\text { Penstabil CMC (p2) } \\
0,4 \%\end{array}$ & 29.11 & 32.15 & & 34.16 \\
\hline $\begin{array}{c}\text { Penstabil CMC (p3) } \\
0,6 \%\end{array}$ & a $\quad 38.85$ & 40.10 & & 41.92 \\
\hline
\end{tabular}

Keterangan : Setiap huruf yang berbeda menunjukkan perbedaan yang nyata pada taraf 5\%. Huruf besar dibaca vertikal dan huruf kecil dibaca horizontal.

Semakin tinggi konsentrasi penstabil CMC yang digunakan maka semakin berpengaruh terhadap waktu larut kokristalisasi sari bonggol nanas. Hal ini menunjukan bahwa semakin tinggi penambahan sukrosa pada kokristalisasi sari bonggol nanas maka semakin lama waktu larutnya. Hal tersebut dapat disebabkan karena sifat CMC koloid dan dapat mengikat, dan suhu air yang digunakan berkisar 60-65OC sehingga kemudahan larut dalam air pun berbeda. Sukrosa memiliki kristal bersifat amorphis, dengan titik leleh 160oC pada tekanan 1 atmosfer, berasa manis, sangat mudah larut dalam air, mudah terhidrolisis oleh asam dan enzim (Moerdokusumo,1993).

Menurut Siregar dkk. (2010), waktu dispersi atau nama lainnya waktu larut adalah waktu yang dibutuhkan granul untuk larut secara sempurna dalam air. Faktor yang mempengaruhi kelarutan (waktu larut) adalah ukuran, luas permukaan, dan kadar air granula. Ukuran partikel yang seragam dan luas permukaan bubuk yang meningkat menyebabkan kelarutan tinggi (waktu larut cepat) (Sari, 2016).

4. Uji Organoleptik

a. Warna

Pengaruh konsentrasi CMC dan konsentrasi sukrosa terhadap warna kokristalisasi sari bonggol nanas dapat dilihat pada Tabel 6.
Berdasarkan Tabel 6 di bawah menunjukkan semakin meningkatnya skala numeric angka maka produk tersebut semakin disukai oleh konsumen. Semakin tinggi konsentrasi sukrosa berpengaruh pada atribut warna. Dimana semakin tinggi konsentrasi sukrosa yang ditambahkan maka panelis semakin menyukai warna kokristalisasi sari bonggol nanas, karena memberikan nilai rata-rata warna yang besar yaitu 3,911 atau 4 dimana panelis memberikan penilaian agak suka terhadap warna kokristalisasi sari bonggol nanas. Hal ini dikarenakan banyak jumlah sukrosa yang digunakan maka warna kokristalisasi sari bonggol nanas semakin gelap, yang dimana sukrosa akan larut ke dalam campuran sari buah dan saat dipanaskan akan menyebabkan reaksi Maillard, yang mana menyumbangkan warna kuning-kecoklatan. Hal ini disesuaikan dengan pernyataan Jing, dkk. (2009) yang menyatakan bahwa penambahan jumlah sukrosa yang diikuti oleh kenaikan nilai skor warna, mengindikasikan warna semakin coklat.

Tabel 6. Uji Dwi Arah untuk Interaksi Konsentrasi CMC dan Sukrosa terhadap Atribut Warna Kokristalisasi Sari Bonggol Nanas

\begin{tabular}{|c|c|c|c|}
\hline \multirow{2}{*}{ Penstabil (CMC) } & \multicolumn{3}{|c|}{ Sukrosa } \\
\hline & Sukrosa (s1) 50\% & Sukrosa (s2) 55\% & Sukrosa (s3) $60 \%$ \\
\hline$\frac{\text { Penstabil CMC (p1) }}{0,2 \%}$ & 4,022 & 3,700 & 4,689 \\
\hline $\begin{array}{c}\text { Penstabil CMC (p2) } \\
0,4 \%\end{array}$ & 3,911 & 4,211 & 4,311 \\
\hline $\begin{array}{c}\text { Penstabil CMC (p3) } \\
0,6 \%\end{array}$ & 3,400 & 4,322 & 3,722 \\
\hline
\end{tabular}

Keterangan : Setiap huruf yang berbeda menunjukkan perbedaan yang nyata pada taraf 5\%. Huruf besar dibaca vertikal dan huruf kecil dibaca horizontal.

Penambahan sukrosa ke dalam suatu bahan akan memberikan konstribusi terhadap warna, yaitu warna yang semakin tua pada produk tersebut. Selama pemanasan berlangsung suhu akan meningkat sehingga dapat mengakibatkan warna produk menjadi gelap (Winarno, 1984).

Menurut Winarno (1997), bahwa ada lima hal yang menyebabkan suatu bahan berwarna, yaitu pigmen yang secara alami terdapat dalam tanaman dan hewan, reaksi karamelisasi, warna gelap yang timbul akibat reaksi maillard, reaksi oksidasi oleh adanya enzim dan penambahan zat warna.

\section{b. Aroma}

Berdasarkan hasil Analisis Variansi (ANAVA) terhadap uji organoleptik atribut aroma kokristalisasi sari bonggol nanas menunjukkan bahwa konsentrasi penstabil CMC (P), konsentrasi sukrosa (S) dan interaksi (PS) berpengaruh terhadap atribut aroma kokristalisasi sari bonggol nanas. Pengaruh konsentrasi CMC dan konsentrasi sukrosa terhadap aroma kokristalisasi sari bonggol nanas dapat dilihat pada Tabel 7. 
Tabel 7. Uji Dwi Arah untuk Interaksi Konsentrasi CMC dan Sukrosa terhadap Atribut Aroma Kokristalisasi Sari Bonggol Nanas

\begin{tabular}{|c|c|c|}
\hline Penstobilcauci & & \\
\hline Penstabil (CMC) & Sukrosa (s1) 50: & \\
\hline$\frac{\text { Penstabil CMC (p1) }}{0,2 \%}$ & 4,178 & \\
\hline$\frac{\text { Penstabil CMC (p2) }}{0,4 \%}$ & a $\quad 3,989$ & \\
\hline$\frac{\text { Penstabil CMC (p3) }}{0,6 \%}$ & a 3,322 & \\
\hline
\end{tabular}

Keterangan : Setiap huruf yang berbeda menunjukkan perbedaan yang nyata pada taraf 5\%. Huruf besar dibaca vertikal dan huruf kecil dibaca horizontal.

Berdasarkan Tabel 7 menunjukkan semakin meningkatnya skala numeric angka maka produk tersebut semakin disukai oleh konsumen.

Berdasarkan pada semakin tinggi konsentrasi CMC pada konsentrasi sukrosa maka berpengaruh terhadap atribut aroma. Hal ini dikarenakan buah yang digunakan adalah buah nanas dan hanya diambil sari bonggolnya saja, Semakin banyak sari bonggol nanas yang ditambahkan maka skor aroma semakin meningkat, maka panelis semakin menyukai aroma kokristalisasi sari bonggol nanas, karena memberikan nilai rata-rata aroma yang besar yaitu 3,989 atau 4 dimana panelis memberikan penilaian agak suka terhadap aroma kokristalisasi sari bonggol nanas. terjadinya peningkatan skor aroma disebabkan oleh adanya asam sitrat pada nanas. Sedangkan penilaian aroma dipengaruhi faktor psikis dan fisiologi yang memberikan pendapat berlainan (Kartika, dkk. 1987).

Aroma merupakan salah satu parameter identifikasi flavor yang paling mudah dan paling sering dilakukan. Aroma dapat didefinisikan sebagai sesuatu yang dapat diamati dengan indera penciuman. Aroma yang bau yang diukur sehingga biasanya menimbulkan pendapat yang berlainan dalam menilai kualitas aromanya. Perbedaan pendapat disebabkan tiap orang memiliki perbedaan penciuman meskipun mereka dapat membedakan aroma namun setiap orang mempunyai kesukaan yang berlainan (Kartika, dkk, 1988).

\section{c. Rasa}

Rasa dari produk makanan pada umumnya tidak hanya terdiri dari satu rasa saja akan tetapi merupakan gabungan berbagai macam yang terpadu sehingga menimbulkan cita rasa makanan yang utuh (Kartika, dkk,1988).

Berdasarkan hasil analisis menunjukkan bahwa konsentrasi penstabil CMC (P) dan konsentrasi sukrosa (S) berpengaruh terhadap rasa kokristalisasi sari bonggol nanas, sedangkan konsentrasi CMC serta interaksi antara konsentrasi sukrosa tidak berpengaruh. Pengaruh konsentrasi penstabil CMC $(\mathrm{P})$ terhadap rasa kokristalisasi sari bonggol nanas dapat dilihat pada Tabel 8.
Tabel 8. Uji Lanjut Duncan Konsentrasi CMC terhadap Atribut Rasa Kokristalisasi Sari Bonggol Nanas

\begin{tabular}{|l|l|l|}
\hline \multicolumn{1}{|c|}{ Perlakuan } & \multicolumn{1}{|c|}{ Nilai rata-rata } & \multicolumn{1}{c|}{ Taraf nyata 5\% } \\
\hline $\mathrm{s}_{1}$ & 4,119 & $\mathrm{~A}$ \\
\hline $\mathrm{s}_{2}$ & 4,344 & $\mathrm{~B}$ \\
\hline $\mathrm{s}_{3}$ & 4,541 & $\mathrm{~B}$ \\
\hline
\end{tabular}

Keterangan : Nilai rata-rata yang ditandai dengan huruf yang sama menunjukkan tidak berbeda nyata pada taraf $5 \%$ menurut uji lanjut Duncan

Berdasarkan Tabel 8 di atas dapat dilihat bahwa perbedaan setiap jenis konsentrasi CMC yang digunakan, maka semakin meningkat nilai rata-rata yang besar yaitu 3,911 atau 4 dimana panelis memberikan penilaian agak suka terhadap rasa kokristalisasi sari bonggol nanas. Hal ini dapat terjadi diduga karena rasa terhadap kokristalisasi sari bonggol nanas dengan penambahan CMC tidak berpengaruh interaksi dan sehingga sama-sama kuat.

Pengaruh konsentrasi penstabil sukrosa (S) terhadap rasa kokristalisasi sari bonggol nanas dapat dilihat pada Tabel 9.

Tabel 9. Uji Lanjut Duncan Konsentrasi Sukrosa terhadap Atribut Rasa Kokristalisasi Sari Bonggol Nanas

\begin{tabular}{|l|l|l|}
\hline \multicolumn{1}{|c|}{ Perlakuan } & \multicolumn{1}{|c|}{ Nilai rata-rata } & \multicolumn{1}{c|}{ Taraf nyata 5\% } \\
\hline $\mathrm{s}_{1}$ & 4,119 & $\mathrm{~A}$ \\
\hline $\mathrm{s}_{2}$ & 4,344 & $\mathrm{~B}$ \\
\hline $\mathrm{s}_{3}$ & 4,541 & $\mathrm{~B}$ \\
\hline
\end{tabular}

Keterangan : Nilai rata-rata yang ditandai dengan huruf yang sama menunjukkan tidak berbeda nyata pada taraf $5 \%$ menurut uji lanjut Duncan

Berdasarkan Tabel 9 di atas dapat dilihat bahwa perbedaan setiap jenis konsentrasi sukrosa yang digunakan, maka semakin meningkat nilai rata-rata kesukaan panelis besar 4 dimana panelis memberikan penilaian agak suka terhadap rasa kokristalisasi sari bonggol nanas. Hal ini dapat terjadi diduga karena faktor konsentrasi CMC dan konsentrasi sukrosa samasama kuat dan sehingga tidak bisa saling mempengaruhi satu sama lain.

Rasa adalah faktor yang cukup penting dari suatu produk makanan, penilaian cita rasa menunjukkan penerimaan konsumen terhadap suatu bahan makanan, yang umumnya dilakukan dengan penilaian dengan indera manusia. (Winarno, 1997).

Berdasarkan hasil penelitian, dapat diambil kesimpulan sebagai berikut :

1. Jumlah penstabil CMC berpengaruh terhadap kadar air, waktu larut, uji organoleptik aroma, dan warna. Namun tidak berpengaruh terhadap analisis kadar vitamin $\mathrm{C}$ dan uji organoleptik atribut rasa.

2. Jumlah sukrosa berpengaruh terhadap kadar air, waktu larut, uji organoleptik atribut warna, dan aroma. Namun tidak berpengaruh terhadap analisis kadar vitamin $\mathrm{C}$ dan uji organoleptik atribut rasa.

3. Interaksi antara jumlah penstabil CMC dan sukrosa berpengaruh terhadap kadar air, waktu larut, uji organoleptik atribut warna, dan aroma. Namun tidak berpengaruh terhadap analisis kadar vitamin $\mathrm{C}$ dan uji organoleptik atribut rasa. 


\section{Daftar Pustaka}

1. [AOAC] Association of Official Analytical Chemistry. (1995). Official Methods of Analysis 932.12 Solids (Soluble) in Fruits and Fruit Products. Virginia.

2. Buckle K.A., Edward R.A., Fleet G.H., dan Wootton M, (1987). Ilmu Pangan. (Terjemahan). UI Press, Jakarta

3. Burhanudin. (2003). Pengaruh Penambahan Konsentrasi Bubur Buah Dan Konstrasi Sukrosa Pada Pembuatan Alpuket Instan (Persea americana) Dengan Metode Kokristalisasi. Skripsi, Jurusan Teknologi Pangan, Fakultas Teknik, Universitas Pasundan, Bandung.

4. Dinas Pertanian Tanaman Pangan Kabupaten Subang. Subang Dalam Angka Tahun 2013. Badan Statistik Kabupaten Subang.

5. Fardiaz, S., (1992). Mikrobiologi Pangan I. Gramedia Pustaka Utama, Jakarta.

6. Firmansyah, D. (2008). Pengaruh Konsentrasi Asam Sitrat Dan Perbandingan Sukrosa Dengan Glukosa Terhadap Karakteristik Manisan Semi Basah Bonggol Nenas (Ananas comosus l. merr). Skripsi, Prodi Teknologi Pangan, Fakultas Teknik, Universitas Pasundan, Bandung

7. Hutagalung, T. Nainggolan, R. Nurminah, M (2015). Pengaruh Perbandingan Bubur Buah Nanas dengan Bubur Wortel dan Jenis Zat Penstabil Terhadap Mutu Selai Lembaran. Skripsi, Prodi Ilmu dan Teknologi Pangan, Fakultas Pertanian, USU Medan.

8. Kartika, B. (1988). Pedoman Uji Inderawi Bahan Pangan. Universitas Gajah Mada, Yogyakarta.

9. Kamal, N. (2010). Pengaruh Bahan Aditif CMC (Carboxyl Methyl Cellulose) Terhadap Beberapa Parameter Pada Larutan Sukrosa. Jurnal Teknologi Vol. 1, Edisi 17.

10. Kementerian Pertanian. (2016). Pusat Data dan Informasi Pertanian. Sekretariat Jenderal

11. Ngakan, Timur Antara. (1994), Mikroenkapsulasi Flavour Jeruk dengan Cara Kokristalisasi, BBPIHP, Bogor.

12. Ngakan, T.A., (1997), Aplikasi Teknik Kokristalisasi dalam Pengembangan Produk Minuman Sehat, BBIHP, Bogor

13. Siddiq, O.F., (2003). Pengaruh Konsentrasi Sukrosa Dan Penambahan Asam Sitrat Terhadap Karakteristik Rambutan (Nephelium lappaceum) Instan Dengan Metode Kokristalisasi. Skripsi, Jurusan Teknologi Pangan, Fakultas Teknik, Universitas Pasundan, Bandung.

14. Sucipto. (2006). Pengaruh Tingkat Kematangan (Mentah, Matang dan Lewat Matang) dan Konsentrasi Aseton Terhadap Jumlah Enzim dengan Pengujian Aktivitas Enzim Bromelin Pada Buah Nenas (Ananas comosus l. merr). Skripsi, Jurusan Teknologi Pangan, Fakultas Teknik, Universitas Pasundan, Bandung.
15. Tranggono, (1988). Bahan Tambahan Pangan (Food Aditives). Pusat Antar Universitas Pangan dan Gizi, Universitas Gajah Mada, Yogyakarta.

16. Winarno, F.G. (1992). Kimia Pangan dan Gizi, PT. Gramedia Pustaka Utama, Jakarta.

17. Winarno, F.G. (1997). Kimia Pangan dan Gizi. Cetakan ke VIII. Penerbit PT. Gramedia Pustaka Utama, Jakarta. 